\title{
How do they know? Practicing knowledge in comparative perspective.
}

Forthcoming in Qualitative Sociology, Special Issue on Knowledge in Practice, Fall 2010

Claudio E. Benzecry and Monika Krause

\section{Introduction}

In the past 10 years or so we have seen a convergence of interest in knowledge and practice in various substantive areas of sociological inquiry. Scholars in the tradition of science and technology studies had first shown that science and technology, too, could be subject to sociological inquiry and then turned their attention to empirical sites beyond the natural sciences. In a separate movement, the influence of the work of Pierre Bourdieu has given new impetus to the efforts of scholars of other realms of social life to focus on the dimension of knowledge in their research. These intellectual movements added to the classical and ongoing contributions to the sociology of knowledge and culture and in the tradition of ethnomethodology and symbolic interactionism.

Scholars in the different traditions approaching knowledge share some common ground; yet they also draw on distinct contributions from specific scholars in different theoretical traditions. These theoretical differences can lead scholars in one school to ignore the work of other schools. More helpfully, they can provoke arguments and debate. Most importantly, we think, it is an opportunity for a discussion not just of the relative value of one theoretical approach or the other but for comparative empirical investigation into how knowledge is practiced across different empirical settings and how 
aspects emphasized by different approaches matter empirically. We assemble this issue with this interest in mind, with empirical contributions on such topics as medicine, art, the state, financial games, science, and Buddhist meditation.

Most of the papers assembled in this special issue were originally presented at the 2009 Junior Theorist Symposium, held to coincide with the Annual Meeting of the American Sociological Association in San Francisco. The symposium aims to create a space for advanced graduate students and junior faculty to focus on the conceptual and theoretical aspects of their work. The symposium itself provided further evidence of this expanding interest in knowledge - in response to a very open call for papers about 'theory', knowledge emerged as a key theme among the submissions. While this is not a representative sample it gives some indication of the interests of young scholars who think of their work as 'theoretical'; as most of the presenters were drawing on their dissertation work, it gives some indication also as to one kind of $\mathrm{PhD}$ thesis written in U.S. sociology today.

The Junior Theorist Symposium has been sponsored by the Theory Section of the ASA since 2005, and it is beginning to be the site of dialogue not just between junior theorists and senior commentators but also among different cohorts of presenters. In this spirit, we are pleased that the organizers of the very first Symposium, Neil Gross and Marion Fourcade, have agreed to contribute an afterword to this special issue.

The following introduction will, very briefly, outline the trajectories of different sociologies of knowledge and introduce the articles that follow in light of some the questions raised by the dialogue between them. We are not aiming for a complete literature review on knowledge in sociology or the social studies of science and 
technology, but rather to show the diverse strains that have been appropriated by scholars who discuss the production, dissemination and consumption of knowledge as a practical activity.

\section{Sources}

STS beyond science

Science and Technology Studies emerged as an interdisciplinary field, bringing together scholars with positions in sociology, history, philosophy, anthropology, and literary studies (Zammito 2004, Siler 2009). Initially these scholars were interested in how scientists know nature, and in the role of technology in everyday life, drawing on the sociology of science and the history of science but with a new constructivist impetus. Some of the scholars who made leading contributions to the sociology of science have moved to do research on other areas of social life. Karin Knorr-Cetina, the author of a very influential ethnography of scientists, published the Sociology of Financial Markets in 2004 (Knorr-Cetina and Preda 2004). Donald McKenzie, one of the key proponents of the strong programme in the sociology of knowledge began announcing "Modern Finance” as a topic of Science studies in 2001 and is currently a professor of the social studies of finance (McKenzie 2001, McKenzie 2006, 2008, McKenzie, Muiesa, Siu 2007). Michel Callon has contributed to the sociology of markets from the perspective of actor-network-theory (Callon 1998, Callon, Millo Muniesa 2007, Caliskan and Callon 2009). Bruno Latour has of course also worked on diverse topics such as religion and law (e.g. Latour 2009). Recently, there has also been work on architecture and urban studies (e.g. Farias and Bender, 2009), on art (e.g. Hennion, 1993, 2001, 2007; Hennion and 
Gomart, 1999; Born, 1995), and extensions into politics and policy (e.g. Barry 2001, Lezaun and Soneryd 2007). The conference programmes of the Society for the Social Study of Science indicate a space where scholars come together by sharing a specific set of references and theoretical assumptions rather than a specific object of inquiry. Scholars in this tradition share a focus on practice; initially in the laborarory (Latour and Woolgar 1979, Knorr-Cetina 1981), and beyond it (Cetina, Schatzki and Savigny 2001). The practical character of producing knowledge can also be observed in a central debate of this tradition: the differentiated role that experts and laymen play. Scholars have focused on how professionals claim jurisdiction and autonomy over contested fields of knowledge and the particular cultural and organizational strategies they pursue. For instance research has scrutinized how the boundaries between science and non-science have been established (Gieryn 1983, 1999) and shown that scientists draw on social norms (i.e. trust and civility) to make assessments of valid knowledge (Shapin 1995).

Several specific strengths are common in this tradition, and in particular to ActorNetwork Theory. On the one hand, scholars try to radically go beyond pre-empirical assumptions about traditional sociological categories (e.g. “art”, “science”, “class”). They use methods that focus closely on practice and situated contexts without accepting the confines traditionally associated with "micro"-sociology. They also focus on the important role of objects and technologies and the importance of material culture more generally, showing how objects are enablers of forms of activity and selfhood. It is the dynamism of STS as an intellectual movement, and of ANT as a theoretical framework that is triggering much of the current debate across areas of inquiry. 


\section{Ethnomethodology and Symbolic Interactionism}

Scholars in the sociology of science broadly draw upon phenomenology and ethnomethodology and these frameworks have also had their own life in sociology, shaping debates in the sociology of art, of religion, and to a lesser extent of politics. Drawing on Husserl and later Schütz (1967), Berger and Luckman (1966) and Garfinkel (1967), scholars in these fields have examined how knowledge about and meanings within the world are inter-subjectively constructed.

Following Garfinkel, for instance, Sudnow (1978) has shown how the description of a mundane experience such as playing jazz on the piano, involves the a focus on bodily conduct as well as redefinitions of the meanings of "jazz", "chords" and "songs.". Presenting shopfloor-like scenes of the work of forensic pathologists, Timmermans (2006) shows the contingent situated practices of performing tasks, doing work together, and transforming it together, emphasizing the interaction between practice, the organizational context and the substantive content that is obtained through work to decipher the meaning of death.

Drawing on the pioneer ethnographic work of Everett Hughes (1984), Howard Becker $(1961,1982)$ has emphasized how diverse social worlds -arts, medical students, teachers- are comparable in a few aspects: the processes of socialization and initiation; the ceremonies that produce membership; and the mechanisms that set the boundaries between disciplines that share similar codes. If enthnomethodology's strength has been to fully include the content of knowledge in the analysis, symbolic interactionists have been alert to the specialized worlds in which activity takes place. 
The concept of the art world allowed Becker to show how cultural objects are collectively produced, division of labor that this entails and how conventions are central to make the cultural product less costly and more effective. He also showed how these conventions anchor networks that involve producers, distributors and audience members in a collaborative fashion. The work of Andrew Abbott (1988) on professions and experts, also falls into this tradition, studying professions within the context of the ecology of professions, much like his predecessors at the University of Chicago studied neighborhoods.

Becker (1992) entered into a fruitful dialogue with the work of Bruno Latour (1987) and incorporated concepts like dispositive, package or apparatus in later papers on the matter, showing how collective activity imposes constraints on cultural innovation and the way this solidifies in cultural materials like instruments and notations. Moreover, his latest work with Rob Faulkner (Becker and Faulkner 2009) incorporates lessons from the world of laboratory studies, in showing how the standard jazz repertory is assembled, by showing it is not by the laborious introjection of an $\mathrm{x}$ amount of pieces but rather by improvising together based on the harmonic progression of the music at hand. knowledge gets both transmitted and produced in the process of making music.

\section{Sociology of Knowledge}

Building on themes in classical sociology, the sociology of knowledge following Mannheim has examined how knowledge and ideas are shaped by social positions, organizational and structural factors. The investment of this tradition in questions about how "good” knowledge can be produced - either by bracketing particular social 
constraints and/or by producing social institutions that foster truth - and with the specific potential of the 'human' sciences has limited its empirical attention to scientific work and provided the foil for the breakaway of the sociology of scientific knowledge.

With regard to knowledge in other areas there has arguably been more continuity. There has been a continued interest and research, for example, in the role of expert groups, professions and disciplines (e.g., Eyal, Szelenyi and Townsley 1998, Eyal 2003, Bockman and Eyal 2002, Guilhot 2005, Fourcade 2009).

In recent developments, there has been a new interest in the content of ideas and the micro-contexts and networks that shape them in the "new sociology of ideas"(Camic 1983, Collins 1998, Camic and Gross 2004, Gross 2008).

Scholars have also brought together the study of social movements and the sociology of knowledge and science in new ways. This interest is evident in studies of the role of social movements and the role of lay activists in science (Epstein 1996, Moore 2008, Frickel 2004, Moore and Frickel 2006); and in studies of the interface between social and intellectual movements (Frickel and Gross 2005). There has also been an interest in new challenges to the autonomy of science, such as how the growing role played by pharmaceutical companies challenges the autonomy of medical, psychiatric and psychoanalytic knowledge (Lakoff 2006, Petryna 2009).

\section{The impact of Bourdieu.}

The reception of the work of Pierre Bourdieu in the US has given new momentum for scholars of other realms of social life to focus on the dimension of knowledge in their research, arguably in some continuity with the concerns of the sociology of knowledge. 
On, the one hand are close studies of habitus that center on the production of subjectivities through particular kinds of knowledge that are learned in the making (Wacquant 2003, Desmond 2007, O’Connor 2005), and studies of fields (Ferguson 1998, Lamont 1987, Benson 1999). This scholarship has looked at the production of knowledge from the inside out (its embodied, tacit character) as well as its institutional organization, inquiring about how resources are distributed, which groups are favored and what consequences that has for knowledge production. On the first account, the literature on craft has shown how in the production of knowledge, processes of self-construction and self-transcendence happen through the body -Sennett (2008), O’Connor (2005), Wacquant (2003), Rotella (2002) and Harper (1987)-, while the latter has shown the relationship between these particular positions and the accumulation of both endogenous and outside resources within a sphere of activity.

\section{Stakes}

These streams have some common enemies and many shared interests. They all try to go beyond epistemology as a philosophical endeavor towards an empirical approach, and all ask not how the world is but how it is constructed (and how it has come to be, partly as a consequence of these constructions). They also largely share an interest in looking beyond "shared values" and "ideologies”, towards a focus on practice. In this regard, they center on how things are known, the processes through which this happens,. As such they pay in depth-attention to the substantive contents and the form of the knowledge produced. In producing a more thorough and nuanced account of how people 
enact and achieve knowledge in particular circumstances, they also provide a more convincing explanation of why that particular form of knowledge came to be.

The divisions between traditions have some reasons that are historical and institutional, sometimes personal; but the debate also has significant intellectual stakes, such as debates over:

(1) whether sociology can be applied to nature and the natural sciences

(2) The status of the objects of knowledge and the status of material culture

(3) The status of the content of knowledge and ideas.

(4) The role of power in social life,

(5) The status of self-descriptions and the role of the scholar and of critique vis-à-vis these self descriptions,

(6) And the status of meso and macro contexts of social life, such as differentiated fields of practice or class structures, and cultures.

\section{Questions}

Studying knowledge across empirical settings opens up new materials for dialogue across traditions based on the comparison of empirical materials. This comparison has begun of course but it has been hindered by a lack of agreement over what might be appropriate units of comparisons (fields? Hybrid assemblages? Timeperiods? National contexts?); and by the temptation to assert superiority on pre-empirical grounds.

To take the question of "fields", as an example, micro-sociologists and ANT have shown an extreme skepticism towards the reality of a relative coherence of practices in 
specific realms of social life, be they understood as fields, systems, spheres, and worlds While this has yielded many critical insights it has sometimes become a creed rather than a proposition that could be tested empirically. Sociologists looking at "fields of practice", on the other hand, might be charged with a tendency to speak too quickly of 'fields' as though we could assume such a coherence and with a tendency to imply that an analysis of fields would make redundant close attention to practices and tools.

The papers of this special issue focus on knowledge practices in a variety of empirical settings: we read about people practicing Buddhist meditation, art curators placing objects, state managers counting the beneficiaries of a project, doctors trying to explain cholera, think tank experts juggling to fulfill their many roles, financial enthusiasts playing board games in order to become responsible economic subjects, and native Canadians and scientists counting clams. In addition to the specific questions these papers address, they speak to a number of questions arising out of that dialogue across traditions.

These papers stand in a long sociological tradition. They ask how different claims to truth are adjudicated and what kind of social order is produced. They emphasize different factors and mechanism: Sophia Accord highlights the role objects, Owen Whooley the role of organizations, and Chantelle Marlor the role of the state.

Our authors have also clearly learned from the social studies of science and technology, as well as of finance and accounting, when they ask what we can learn from looking closely at objects and tools in different areas. Sophia Accord, for example, looks at the role objects play in the work of elite curators; Daniel Fridman looks at the board games where hopeful everyday people learn economic and financial tools. 
The papers also compare knowledge practices of people who are (professional) scientists to those who are not. Michal Pagis, for example, compares the monastery to the laboratory and finds that Buddhists too, establish controlled environments for the creation of knowledge and then struggle to make this knowledge relevant outside that space. All papers ask for new variations in the ways knowledge is practiced (and contested).

Chantelle Marlor wants to draw attention to the property of "manufactured transparency", which links scientific knowledge and the neoliberal state in an elective affinity. Monika Krause discusses a new way in which the state imagines the people, namely as countable beneficiaries of policy interventions. Michal Pagis, drawing on her research on meditation, offers a framework for analyzing the different ways in which bodily and abstract knowledge are linked in practice.

Lastly, some of the papers specifically examine the link between different forms of the state and different knowledge practices. Chantelle Marlor and Monika Krause (re)examine some of the implications of what is sometimes referred to as the neoliberal state. In a research note, Tom Medvetz discusses some of the findings from his study of the new role of political think tanks.

In "Kafka and its precursors” Jorge Luis Borges postulated a radical hermeneutical model that took apart the idea of chronological influence and proposed instead an inverted modus operandi in which every writer creates its own precursors. He argued that Kafka's writings allow the construction of a family resemblance with a series of pre-existent texts, since it is possible to recognize the voice of Kafka in the texts of writers as diverse as Kierkegaard, Bloy, Browning and Lord Dunsany. Without Kafka, the analogy uniting these literatures from different epochs and places would not have 
been noticed. This issue of Qualitative Sociology arms itself with a similar spirit, hoping that the many papers that make this symposium up can illuminate the relationship between knowledge and practice, signaling retrospectively the potential points of convergence among the many traditions that have at various junctions preferred to present themselves in opposition to each other or ignored each other completely. Contributors to this special issue employ various theoretical orientations and narrative choices to make sense of the specific universes under investigation. Through multiple problématiques, objects, orientations, and writing styles, the following pages show the influence of the many streams that have inquired about the practical character of knowledge and their intersections. What we hope is that they also glance towards what it

might look like to address some of the theoretical stakes outlined above through an empirical comparison across settings.

\section{References}

Abbott, A. (1988). The System of Professions. Essay on the Division of Expert Labour. Chicago: University of Chicago Press.

Barry, A. (2001). Political machines: Governing a technological Society. London and New York: Athlone Press.

Becker, H. (1961). Boys in White. Chicago: University of Chicago Press. . (1982). Art Worlds. Berkeley: University of California Press. . (1995). “The Power of Inertia.” Qualitative Sociology, 18 (3), 301-309.

Becker, H. and Faulkner, R. (2009). Do you Know? The Jazz Repertoire in Action. Chicago: University of Chicago Press.

Benson, R. (1999). "Field theory in comparative context: a new paradigm for media studies." Theory and Society, 28 (3), 463-498

Berger, P. L. and Luckmann, T. (1966). The social construction of reality: A treatise in the sociology of knowledge. Garden City: Anchor Books.

Bockman, J. and Eyal, G. (2002). "Eastern europe as a laboratory for economic knowledge: The transnational roots of neoliberalism. American Journal of Sociology, 108 (2), 310-352.

Born, G. (1995). Rationalizing Culture. Berkeley: University of California Press. 
Caliskan, K. and Callon, M. (2009). Economization, part 1: Shifting attention from the economy towards processes of economization. Economy and Society, 38(3), 369 398.

Callon, M. (ed.). (1998). The laws of the market. Oxford: Blackwell.

Callon, M., Millo, Y. and Muniesa, F. (eds.). (2007). Market devices. Oxford: Blackwell.

Charles C. and Gross, N. (2004). "The new sociology of ideas" in J. R. Blau, The Blackwell companion to sociology. Malden-Oxford: Blackwell.

Charles C. (1983). Experience and enlightenment: Socialization for cultural change in Eighteenth-Century Scotland. Chicago: University of Chicago Press.

Collins, R. (1998). The sociology of philosophies: A global theory of intellectual change. Cambridge: Harvard.

Desmond, M. (2007). On the Fireline. Chicago: University of Chicago Press.

Epstein, S. (1996). Impure Science: AIDS, activism, and the politics of knowledge.

Berkeley: University of California Press.

Eyal, G. (2002). "Dangerous liaisons between military intelligence and Middle Eastern studies in Israel." Theory and Society, 31 (5), 1573-7853.

Eyal, G., I. Szelenyi and E. Townsley. (1998). Making capitalism without capitalists. The new ruling elites in europe. New York: Verso.

Farias, I. and Bender, T/ (eds.) (2009). Urban assemblages: how actor-network theory changes urban studies. London/New York: Routledge.

Ferguson, Priscila. (1998). "A Cultural Field in the Making: Gastronomy in 19th-century France.” American Journal of Sociology, 103 (3), 597-641.

Fourcade, M. (2009). Economists and societies: Discipline and profession in the United States, Britain, and France, 1890s to 1990s. Princeton: Princeton: University Press.

Frickel, S. (2004). Chemical Consequences: Environmental Mutagens, Scientist Activism and the Rise of Genetic Toxicology. New Brunswick, NJ: Rutgers University Press.

Frickel, S. and Moore, K. (eds.) (2006). The New Sociology of Science: Organizations, Networks, and Institutions. University of Wisconsin Press

Frickel, S. and Gross, N. (2005). "A General Theory of Scientific/Intellectual Movements." American Sociological Review, 70 (2), 204-232.

Garfinkel,H. (1967). Studies in ethnomethodology. Englewood Cliffs: Prentice Hall.

Gieryn, T. F. (1983). Boundary-work and the demarcation of science from non-science: Strains and interests in professional ideologies of scientists. American Sociological Review, 48(6), 781-795.

Gieryn, T. F. (1999). Cultural boundaries of science: Credibility on the line. Chicago:

University of Chicago Press.

Gross, N. (2008). Richard Rorty. The making of an American philosopher. Chicago: University of Chicago Press.

Guilhot, N. (2005). The democracy makers: Human rights and international order. New York: Columbia University Press.

Harper, D. (1987). Working Knowledge: Skill and Community in a Small Shop.

University of Chicago Press: Chicago.

Hennion, A. (1993). La Passion Musicale. Paris: Metaille.

18 (5), $1-22$.

(2001). "Music Lovers. Taste as Performance". Theory, Culture and Society, 
. (2007). "The things that hold us together. Taste and sociology.” Cultural

Sociology, 1 (1), 97-114.

Hennion, A. and Gomart, E. (1999). “A Sociology of Attachment: Music Amateurs. Drug Users” in Law, John and John Hassard (eds.). Actor Network Theory and After. Oxford:

Blackwell. 220-247.

Hughes, E. (1984). The Sociological Eye: Selected Papers. New Brunswick: Transaction

Publishers.

Knorr-Cetina, K., Schatzki, T and von Savigny, E. (eds.), (2001). The practice turn in contemporary theory. London: Routledge

Knorr-Cetina, K. and Preda, A. (2004). The Sociology of Financial Markets. University Press: Oxford

Knorr-Cetina, K. (1981). The manufacture of knowledge: an essay on the constructivist and contextual nature of science. Oxford: Pergamon Press.

Lakoff, A. (2006). Pharmaceutical Reason. New York: Cambridge University Press.

Lamont, Michele. (1987). "How to Become a Dominant French Philosopher: The Case of

Jacques Derrida.” American Journal of Sociology, 93 (3), 584-622.

Latour, B. and Woolgar, S. (1979). Laboratory life: the social construction of scientific facts. Los Angeles: Sage.

Latour, B. (1987). Science in Action: How to Follow Scientists and Engineers through Society. Cambridge: Harvard University Press.

. (2009). The making of law. An ethnography of the Conseil d'Etat. Cambridge: Polity.

Lezaun, J. and Soneryd, L. (2007). "Consulting citizens: Technologies of elicitation and the mobility of publics.” Public Understanding of Science, 16 (3), 279-297

McKenzie, D., Muniesa, F. and Siu, L. (eds.). (2007). Do economists make markets? On the performativity of economics. Princeton: Princeton University Press.

McKenzie, D. (2001). Physics and finance: S-Terms and modern finance as a topic for science studies. Science, Technology and Human Values, 26, 115-144. . (2006). An engine, not a camera: How financial models shape markets. Cambridge: MIT Press. . (2009). Material markets: How economic agents are constructed. Oxford:

Oxford University Press.

Moore, K. (2008). Disrupting Science: Social Movements, American Scientists, and the Politics of the Military, 1945-1975. Princeton, N.J.: Princeton University Press.

O'connor, E. (2005). "Embodied knowledge: The experience of meaning and the struggle towards proficiency in glassblowing.” Ethnography, 6 (2), 183-204.

Petryna, A. (2009). When experiments travel: clinical trials and the global search for human subjects. Princeton: Princeton University Press.

Rotella, C.(2002). Good with Their Hands. Boxers, Bluesmen and Other Characters from the Rust Belt. Berkeley: University of California Press.

Schutz, A. (1967)[1932]. The phenomenology of the social world. Evanston: Northwestern University Press.

Shapin, S. (1995). A Social History of Truth. Civility and Science in Seventeenth-Century England. Chicago: University of Chicago Press.

Sennett, R. (2008). The Craftsman. New Haven and London: Yale University Press. 
Siler, K. (2009.) Competition, risk/reward structures and scholarly production: The case of science and technology studies. Paper presented at the 2009 Junior Theorist Symposium.

Sudnow, D. (1978). Ways of the hand: the organization of improvised conduct. Cambridge: Harvard University Press.

Timmermans, S. (2006). Postmortem: How Medical Examiners Explain Suspicious Deaths. University of Chicago Press: Chicago.

Wacquant, L. (2003). Body \& Soul: Notebooks of an Apprentice Boxer. New York: Oxford University Press.

Zammito, J. H. (2004). A nice derangement of epistemes: Post-positivism in the study of science from Quine to Latour. Chicago: Chicago University Press. 